\title{
Screening of Some Soybean (Glycine max L. Merrill) Genotypes for Resistance Against Major Insect Pests
}

\author{
L. Murry ${ }^{1 *}$, Imtinaro L. ${ }^{2}$ and T. Jamir ${ }^{3}$
}

${ }^{1,2}$ Dept. of Entomology, ${ }^{3}$ Dept. of Agronomy, School of Agricultural Sciences and Rural Development (SASRD), Nagaland University, Medziphema, Nagaland (797 106), India

\author{
Corresponding Author \\ L. Murry \\ e-mail: lothung.Im@gmail.com
}

\author{
Article History \\ Article ID: AR1864a \\ Received in $15^{\text {th }}$ February, 2018 \\ Received in revised form $22^{\text {nd }}$ March, 2018 \\ Accepted in final form $5^{\text {th }}$ April, 2018
}

\begin{abstract}
A study was conducted in the experimental Research Farm of NU: SASRD, during Kharif, 2016 in order to screen some soybean genotypes for resistance against some major insect pests of soybean using two replications. Thirty-five genotypes (TS 80, JS 21-08, VLS 92, PS 1589, MACS 1543, DS 3105, SL 1104, KDS 1045, DSb 32, RVS 2009-9, MACS 1520, PS 1587, NRC 126, RSC 10-70, KDS 921, Himso 1687, MAUS 711, NSO 626, AMS-MB 5-19, NRC 125, RSC 10-71, PS 1086, TS 70, VLS 93, NRC 127, SL 1113, DS 3106, BAU 100, RSC 10-52, NRC 124, AMS-MB 5-18, MACS 1505, KDS 980, DSb 31 and JS 21-05) of soybean along with three check varieties (JS 7152, RKS 18 and JS 335 ) were used for the study. The major insect pests observed were whitefly (Aleurodicus dispersus), leaf webber (Anarsia ephippias), flea beetle (Systena sp.) and stink bug (Nezara viridula). A separate reading was maintained for each of the soybean genotypes. Insect pests that occurred were recorded at fifteen days interval starting from seven days after germination which was continued till harvest. The genotype DS 3105 (17.25 ten plants ${ }^{-1}$ ) and BAU 100 (5.25 ten plants $\left.{ }^{-1}\right)$ showed highest and lowest infestation by whitefly, respectively. On leaf webber, the highest infestation was found on JS 21-08(4.05 metre row length $\left.{ }^{-1}\right)$ and lowest was found on JS $335\left(0.32\right.$ metre row length $\left.^{-1}\right)$. In case of flea beetle, DS 3106(4.80 metre row length ${ }^{-1}$ ) showed highest infestation while lowest infestation was found on NSO 626(1.63 metre row length ${ }^{-1}$ ). The genotypes RSC 1052(5.9 metre row length ${ }^{-1}$ ) and NRC 124 (5.9 metre row length ${ }^{-1}$ ) reported highest infestation and TS 80(0.4 metre row length ${ }^{-1}$ ) reported lowest infestation by stink bug.
\end{abstract}

Keywords: Soybean, genotype, insect pests, resistance

\section{Introduction}

The soybean (Glycine max L. Merrill) is important food plants cultivated all over the world. It is a legume crop native to East Asia, which contribute to the half of global demand for oil and vegetable protein (FAO, 2013). It also contains $6-7 \%$ total mineral, $5-6 \%$ crude fibre, $5 \%$ ash and $35 \%$ carbohydrates (Chouhan et al. 2002). The total area under soybean cultivation in India during 2005 was about 7.8 ha, which has been steadily rising year after year. At present, total area under soybean cultivation in the country is about $11.6 \mathrm{mha}$. Similarly the production has increased from $7 \mathrm{mt}$ to about $8 \mathrm{mt}$ but the productivity has declined slightly from $897 \mathrm{~kg} \mathrm{ha}^{-1}$ in 2005 to $687 \mathrm{~kg} \mathrm{ha}^{-1}$ in 2015-16 (USDA, 2016). Madhya Pradesh, Maharashtra and Rajasthan contribute about $97 \%$ to the total area and $96 \%$ production of soybean in the country (Anonymous, 2015).

Soybean is also a potential oilseed crop in Nagaland grows well in slopes and terraces and is grown as a pure crop as well as intercrop with maize. It is cultivated in over an area of 24510 ha with the production of $30,680 \mathrm{mt}$, with the productivity of $1.25 \mathrm{mt} \mathrm{ha}^{-1}$. Soybean is mainly grown in Zunheboto District with 7500 ha areas under cultivation, producing about $9620 \mathrm{mt}$. The cultivation of soybean in the state was also popularized by improving sowing time and developing new varieties suitable for cultivation in north eastern plain zone. The suitable varieties recommended by ICAR, for north eastern plain zone which include Nagaland also are as follows: JS80-21, PK472, Pusa 16, JS 335, RAUS 5, Bragg etc (Singh and Sharma, 2013).

During the late sixties and early seventies, the soybean crop was considered to be comparatively safe crop as regards to insect pest attack (Netam and Kanwar, 2013) but now the situation has changed and as many as 275 insect species have been recorded attacking soybean crop in India. Soybean is attacked by about twenty different major insect pests in the country. Amongst these, Girdle beetle, Obereopsis brevis (Swed.) (Coleoptera: Lamiidae) has been reported as a major stem borer pest in Uttar Pradesh, Madhya 
Pradesh, Rajasthan, Delhi, West Bengal, etc. Girdle beetle has been considered to be a cardinal insect pest. The pest recorded infestation from 19.5 to $26.5 \%$ (Kumawat et al., 2010).

Losses caused by incidence of insect pest is one of the important factors leading to the reduced soybean production and productivity (Oerke and Dehne, 2004; Massoni and Frana 2005; Oliveira et al., 2014). The accurate estimates of soybean yield losses caused by insect pests are difficult to be obtained due to environmental conditions, the susceptibility of genotype, the socio-economic conditions of farmers, and the level of technology used (McPherson and McPherson, 2000; Oliveira et al., 2014).

The most economical way to deal with these insect-pests and avoid yield losses is to cultivate insect resistant or tolerant varieties (Awasthi et al., 2005). The use of the resistant plant is proposed to stabilized the yield and has significant advantages over the use of chemical insecticides. It is also proved to be environmentally friendly, minimize the production costs, does not involve the transfer of new technologies and is considered compatible with other control methods used in insect management (Pinheiro et al., 2005; Suharsono and Sulistyowati, 2012).

\section{Materials and Methods}

\subsection{Experimental details}

The layout used for the experimental study was RBD (Randomized Block Design). It was carried out in the field condition during the kharif season (July-Nov) 2016. A total of thirty eight soybean genotypes (TS 80, JS 21-08, VLS 92, PS 1589, MACS 1543, DS 3105, SL 1104, KDS 1045, DSb 32, RVS 2009-9, MACS 1520, PS 1587, NRC 126, RSC 10-70, KDS 921, Himso 1687, MAUS 711, NSO 626, AMS-MB 5-19, NRC 125, RSC 10-71, PS 1086, TS 70, VLS 93, NRC 127, SL 1113, DS 3106, BAU 100, RSC 10-52, NRC 124, AMS-MB 5-18, MACS 1505, KDS 980, DSb 31 and JS 21-05) of soybean along with three check varieties (JS 7152, RKS 18 and JS 335) were used for the study. The field was divided into three replications with each replication having 38 plots of $3 \times 1.4 \mathrm{~m}^{2}$ in size with $1 \mathrm{~m}$ distance between the plots. The plant to plant distance of $10 \mathrm{~cm}$ was kept and the replications were maintained at $1 \mathrm{~m}$ distance. No chemicals were used in the study field.

\subsection{Observation on major insect pest}

- Leaf webber: No. of larva metre row length ${ }^{-1}(\mathrm{mrl})$ was recorded at 3 places in a plot and means were recorded in numbers metre ${ }^{-1}$.

- Flea beetle: No. of adult metre row length ${ }^{-1}$ ( $\left.\mathrm{mrl}\right)$ was recorded at 3 places in a plot and mean was recorded in numbers metre ${ }^{-1}$.

- White fly: No. of insects (nymph and adults) in 3 leaves plants $^{-1}$ (upper, middle and lower leaf) in 10 plants each in a plot was recorded.

- Stink bug: No. of nymph or adult metre row length ${ }^{-1}(\mathrm{mrl})$ was recorded at 3 places in a plot and means were recorded.

\subsection{Categorization of the genotypes}

- Categorization of different soybean genotypes against major insect pests was done following the 'AICRP' method. $\left(\right.$ Sharma, 1996) ${ }^{* *}$

- The treatments were compared among themselves by calculating critical difference $\left(\mathrm{CD}_{0.05}=\mathrm{SEm} \times \mathrm{t}_{0.05}\right.$ for error degrees of freedom)

- The standard error means (SEm) was calculated.

${ }^{* *}$ AICRPs method of categorization (Sharma 1996)

$\mathrm{HR}$ - Value < mean - CD at $1 \%$

$\mathrm{R}-$ Value between mean - CD at $1 \%$ and mean - CD at $5 \%$

HS - Value between mean - CD at $5 \%$ and mean

$\mathrm{LR}$ - Value between mean and mean + CD at $5 \%$

$S-$ Value between mean $+C D$ at $5 \%$ and mean $+C D$ at $1 \%$

$\mathrm{HS}-$ Value $>$ mean $+\mathrm{CD}$ at $1 \%$

\section{Results and Discussion}

3.1. Response of soybean genotypes against leaf webber (Anarsia ephippias, Fabricus)

The means of the larval population count in different genotypes of soybean ranged from as low as 0.32 to as high as 4.05 larvae $\mathrm{mrl}^{-1}$ (Table 1 ). Out of the thirty-eight genotypes of soybean screened, none of the variety showed high susceptibility or high resistance against leaf webber. On the basis of categorization, eight genotypes (VLS 92, MACS 1543, SL 1104, RVS 2009-9, RSC 10-70, AMS- MB 5-19, NRC 125, RSC 10-71) showed low resistance and nine genotypes ( TS 80 , PS 1589, JS 7152, KDS 1045, DSb 32, Himso 1687, NSO 626, NBC 124 and AMS-MB 5-18) were found to be moderately resistant where as fourteen genotypes were found to be resistant (MACS 1520, PS 1587, KDS 921, MAUS 711, VLS 93, SL 1113, DS 3106, BAU 100, RSC 10-52, MACS 1505, JS 335, JS 7152, RKS 18 and JS 21-05) and seven genotypes (JS 21-08, PS 1086, TS 70, NRC 127, KDs 190, Dsb 31 and DS 3105) were found to be susceptible.

The present findings can be compared with the findings reported by Pal et al. (2013) who evaluate 12 soybean cultivars to leaf folders, Nacoleia spp. at Kalimpong, West Bengal, India. Only two cultivars namely, JS (SH) 89-2 and JS (SH) 89-49 were categorized as least susceptible with less than $10 \%$ leaf infestation. Three cultivars viz. JS-80-21, PK-1137 and NRC-24 were found highly susceptible to leaf folders.

3.2. Response of soybean genotypes against whitefly (Aleurodicus dispersus, Gennadius)

Out of the thirty-eight genotypes screened DS 3105 was found to be a highly susceptible genotype against whitefly (17.25 ten plants ${ }^{-1}$ ). BAU-100 showed high resistance against whitefly (5.25 ten plant ${ }^{-1}$ ). Five genotypes (TS 80, MACS 1520, NSO 626, JS 335 and MACS 1-43) exhibited low resistance and fourteen genotypes (VLS 92, RSC 10-70, Himso 1687, AMS-MB 
Table 1: Field screening of soybean genotypes for resistance against major insect pest of soybean during kharif, 2016 and yield obtained

\begin{tabular}{|c|c|c|c|c|c|c|c|c|c|c|c|}
\hline $\begin{array}{l}\text { Sl. } \\
\text { No. }\end{array}$ & Genotypes & $\begin{array}{l}\text { Mean of lar- } \\
\text { vae } \mathrm{mr}^{-1} \\
\text { (Leaf weber) }\end{array}$ & $\begin{array}{l}\text { Cate- } \\
\text { gory }\end{array}$ & $\begin{array}{l}\text { Mean of } \\
\text { adult mrl }{ }^{-1} \\
\text { (White fly) }\end{array}$ & $\begin{array}{l}\text { Cat- } \\
\text { ego- } \\
\text { ry }\end{array}$ & $\begin{array}{c}\text { Mean of } \\
\text { adult } \mathrm{mrl}^{-1} \\
\text { (Flea beetle) }\end{array}$ & $\begin{array}{l}\text { Cat- } \\
\text { egory }\end{array}$ & $\begin{array}{c}\text { Mean of } \\
\text { adult mrl } \\
\text { (Stink bug) }^{-1}\end{array}$ & $\begin{array}{l}\text { Cate- } \\
\text { gory }\end{array}$ & $\begin{array}{l}\text { Yield } \\
\text { (g } \\
\left.\text { plot }^{-1}\right)\end{array}$ & $\begin{array}{c}\text { Yield } \\
(\mathrm{kg} \\
\left.\mathrm{ha}^{-1}\right)\end{array}$ \\
\hline \multirow[t]{2}{*}{1.} & TS 80 & 1.63 & $\mathrm{MR}$ & 11.05 & LR & 2.63 & $R$ & 0.4 & $H R$ & 355 & 845 \\
\hline & & -1.45 & & -3.39 & & -1.76 & & -0.92 & & & \\
\hline \multirow[t]{2}{*}{2.} & JS 21-08 & 4.05 & $S$ & 13.5 & $S$ & 4.53 & $S$ & 0.6 & $\mathrm{HR}$ & 315 & 750 \\
\hline & & -2.13 & & -3.72 & & -2.24 & & -1.01 & & & \\
\hline \multirow[t]{2}{*}{3.} & VLS 92 & 2.5 & LR & 9.15 & $\mathrm{MR}$ & 2.75 & $M R$ & 2.5 & $\mathrm{MR}$ & 890 & 2119 \\
\hline & & -1.73 & & -3.1 & & -1.8 & & -1.73 & & & \\
\hline \multirow[t]{2}{*}{4.} & PS 1589 & 1.75 & MR & 8.55 & $\mathrm{R}$ & 2.75 & $\mathrm{MR}$ & 0.63 & $\mathrm{HR}$ & 540 & 1286 \\
\hline & & -1.5 & & -3 & & -1.8 & & -1.05 & & & \\
\hline \multirow[t]{2}{*}{5.} & MACS 1543 & 2.65 & LR & 11.4 & LR & 2.25 & $R$ & 1.63 & $\mathrm{R}$ & 585 & 1393 \\
\hline & & -1.77 & & -3.45 & & -1.64 & & -1.45 & & & \\
\hline \multirow[t]{2}{*}{6.} & DS 3105 & 2.9 & $S$ & 17.25 & HS & 4.6 & $S$ & 1.92 & $\mathrm{R}$ & 290 & 690 \\
\hline & & -1.84 & & -4.18 & & -2.26 & & -1.54 & & & \\
\hline \multirow[t]{2}{*}{7.} & SL 1104 & 2.75 & LR & 6.75 & $R$ & 4.5 & $S$ & 2.9 & $\mathrm{MR}$ & 770 & 1833 \\
\hline & & -1.8 & & -2.69 & & -2.23 & & -1.84 & & & \\
\hline \multirow[t]{2}{*}{8.} & KDS 1045 & 1.8 & $\mathrm{MR}$ & 8.4 & $R$ & 2.75 & $\mathrm{MR}$ & 3.7 & LR & 697.5 & 1661 \\
\hline & & -1.52 & & -2.98 & & -1.8 & & -2.05 & & & \\
\hline \multirow[t]{2}{*}{9.} & DSb 32 & 1.75 & $\mathrm{MR}$ & 6.9 & $R$ & 3 & $M R$ & 3.05 & $\mathrm{MR}$ & 755 & 1798 \\
\hline & & -1.5 & & -2.72 & & -1.85 & & -1.88 & & & \\
\hline \multirow[t]{2}{*}{10.} & RVS 2009-9 & 2.65 & LR & 7.2 & $R$ & 3.3 & LR & 3.65 & LR & 535 & 1274 \\
\hline & & -1.77 & & -2.77 & & -1.95 & & -2.04 & & & \\
\hline \multirow[t]{2}{*}{11.} & MACS 1520 & 1.5 & $R$ & 11.85 & LR & 3.15 & $\mathrm{MR}$ & 0.73 & $\mathrm{HR}$ & 815 & 1940 \\
\hline & & -1.4 & & -3.5 & & -1.91 & & -1.08 & & & \\
\hline \multirow[t]{2}{*}{12.} & PS 1587 & 0.43 & $\mathrm{R}$ & 7.2 & $\mathrm{R}$ & 3.05 & $\mathrm{MR}$ & 3.75 & LR & 597.5 & 1422 \\
\hline & & -0.96 & & -2.77 & & -1.88 & & -2.06 & & & \\
\hline \multirow[t]{2}{*}{13.} & NRC 126 & 2.15 & $\mathrm{MR}$ & 7.2 & $R$ & 3.55 & LR & 3.75 & LR & 460 & 1095 \\
\hline & & -1.59 & & -2.76 & & -2 & & -2.06 & & & \\
\hline \multirow[t]{2}{*}{14.} & RSC $10-70$ & 2.65 & LR & 11.1 & $\mathrm{MR}$ & 3.75 & $S$ & 4.85 & $S$ & 540 & 1286 \\
\hline & & -1.77 & & -3.4 & & -2.06 & & -2.31 & & & \\
\hline \multirow[t]{2}{*}{15.} & KDS 921 & 1.13 & $\mathrm{R}$ & 6.3 & $R$ & 3.65 & LR & 3.9 & $\mathrm{LR}$ & 232.5 & 553.5 \\
\hline & & -1.22 & & -2.55 & & -2.04 & & -2.1 & & & \\
\hline \multirow[t]{2}{*}{16.} & Himso 1687 & 2.15 & $\mathrm{MR}$ & 9.15 & $\mathrm{MR}$ & 3.55 & LR & 4.2 & $S$ & 525 & 1250 \\
\hline & & -1.59 & & -3.11 & & -2.01 & & -2.17 & & & \\
\hline \multirow[t]{2}{*}{17.} & MAUS 711 & 1.1 & $\mathrm{R}$ & 5.25 & $R$ & 4.75 & HS & 2.65 & $\mathrm{MR}$ & 820 & 1952 \\
\hline & & -1.25 & & -2.39 & & -2.29 & & -1.76 & & & \\
\hline \multirow[t]{2}{*}{18.} & NSO 626 & 2.05 & $\mathrm{MR}$ & 11.7 & LR & 1.63 & $\mathrm{HR}$ & 1.8 & $R$ & 570 & 1357 \\
\hline & & -1.59 & & -3.48 & & -1.45 & & -1.5 & & & \\
\hline \multirow[t]{2}{*}{19.} & AMS-MB 5-19 & 2.8 & LR & 10.2 & $\mathrm{MR}$ & 2.25 & $\mathrm{R}$ & 5.8 & HS & 530 & 1262 \\
\hline & & -1.82 & & -3.26 & & -1.64 & & -2.51 & & & \\
\hline
\end{tabular}




\begin{tabular}{|c|c|c|c|c|c|c|c|c|c|c|c|}
\hline $\begin{array}{l}\text { Sl. } \\
\text { No. }\end{array}$ & Genotypes & $\begin{array}{l}\text { Mean of lar- } \\
\text { vae } \mathrm{mr}^{-1} \\
\text { (Leaf weber) }\end{array}$ & $\begin{array}{l}\text { Cate- } \\
\text { gory }\end{array}$ & $\begin{array}{l}\text { Mean of } \\
\text { adult mrl } \\
\text { (White fly) }^{-1}\end{array}$ & $\begin{array}{l}\text { Cat- } \\
\text { ego- } \\
\text { ry }\end{array}$ & $\begin{array}{c}\text { Mean of } \\
\text { adult mrl' } \\
\text { (Flea beetle) }\end{array}$ & $\begin{array}{l}\text { Cat- } \\
\text { egory }\end{array}$ & $\begin{array}{l}\text { Mean of } \\
\text { adult mrl } \\
\text { (Stink bug) }\end{array}$ & $\begin{array}{l}\text { Cat- } \\
\text { egory }\end{array}$ & $\begin{array}{l}\text { Yield } \\
(\mathrm{g} \\
\left.\text { plot }^{-1}\right)\end{array}$ & $\begin{array}{c}\text { Yield } \\
(\mathrm{kg} \\
\left.\mathrm{ha}^{-1}\right)\end{array}$ \\
\hline \multirow[t]{2}{*}{20.} & NRC 125 & 2.4 & LR & 9.75 & $\mathrm{MR}$ & 2.9 & $M R$ & 3.75 & LR & 742.5 & 1768 \\
\hline & & -1.7 & & -3.2 & & -1.84 & & -2.06 & & & \\
\hline \multirow[t]{2}{*}{21.} & RSC $10-71$ & 2.8 & $\mathrm{LR}$ & 8.4 & $\mathrm{R}$ & 2.95 & $\mathrm{MR}$ & 3.75 & LR & 827.5 & 1970 \\
\hline & & -1.82 & & -2.98 & & -1.86 & & -2.06 & & & \\
\hline \multirow[t]{2}{*}{22.} & PS 1086 & 3.4 & S & 8.25 & $R$ & 4.03 & S & 2.6 & $\mathrm{HR}$ & 302.5 & 720 \\
\hline & & -1.97 & & -2.96 & & -2.13 & & -1.75 & & & \\
\hline \multirow[t]{2}{*}{23.} & TS 70 & 3.35 & $S$ & 7.88 & $\mathrm{R}$ & 3.4 & LR & 2.9 & $\mathrm{MR}$ & 442.5 & 1053 \\
\hline & & -1.94 & & -2.88 & & -1.96 & & -1.84 & & & \\
\hline \multirow[t]{2}{*}{24.} & VLS 93 & 1.5 & $R$ & 8.25 & $R$ & 2.5 & $R$ & 3 & MR & 790 & 1881 \\
\hline & & -1.29 & & -2.93 & & -1.73 & & -1.87 & & & \\
\hline \multirow[t]{2}{*}{25.} & NRC 127 & 2.9 & $S$ & 10.05 & MR & 2.25 & $\mathrm{R}$ & 4.6 & $S$ & 857.5 & 2040 \\
\hline & & -1.84 & & -3.25 & & -1.66 & & -2.26 & & & \\
\hline \multirow[t]{2}{*}{26.} & SL 1113 & 1.28 & $R$ & 10.65 & $\mathrm{MR}$ & 3.5 & LR & 5.9 & HS & 400 & 952 \\
\hline & & -1.27 & & -3.34 & & -2 & & -2.53 & & & \\
\hline \multirow[t]{2}{*}{27.} & DS 3106 & 1.32 & $R$ & 10.95 & $\mathrm{MR}$ & 4.8 & HS & 4.25 & $S$ & 302.5 & 720 \\
\hline & & -1.29 & & -3.38 & & -2.3 & & -2.17 & & & \\
\hline \multirow[t]{2}{*}{28.} & BAU 100 & 1.3 & $R$ & 5.25 & $H R$ & 4.55 & $S$ & 3.15 & $L R$ & 755 & 1798 \\
\hline & & -1.34 & & -2.35 & & -2.25 & & -1.91 & & & \\
\hline \multirow[t]{2}{*}{29.} & RSC $10-52$ & 0.9 & $R$ & 6.6 & $R$ & 2.65 & LR & 5.9 & HS & 312.5 & 744 \\
\hline & & -1.15 & & -2.65 & & -1.77 & & -2.53 & & & \\
\hline \multirow[t]{2}{*}{30.} & NRC 124 & 2 & $\mathrm{MR}$ & 8.85 & $R$ & 2.75 & $\mathrm{MR}$ & 5.9 & HS & 660 & 1571 \\
\hline & & -1.55 & & -3.06 & & -1.8 & & -2.53 & & & \\
\hline \multirow[t]{2}{*}{31.} & AMS-MB 5-18 & 2.15 & $\mathrm{MR}$ & 9 & $\mathrm{MR}$ & 2.4 & $\mathrm{R}$ & 4.8 & S & 280 & 667 \\
\hline & & -1.63 & & -3.07 & & -1.7 & & -2.3 & & & \\
\hline \multirow[t]{2}{*}{32.} & MACS 1505 & 0.9 & $R$ & 10.8 & $\mathrm{MR}$ & 3.15 & $\mathrm{MR}$ & 3.15 & $\mathrm{MR}$ & 254.5 & 606 \\
\hline & & -1.18 & & -3.35 & & -1.91 & & -1.91 & & & \\
\hline \multirow[t]{2}{*}{33.} & KDS 980 & 3 & S & 10.65 & $M R$ & 2.65 & $\mathrm{R}$ & 3.75 & LR & 847.5 & 2017 \\
\hline & & -1.85 & & -3.34 & & -1.77 & & -2.06 & & & \\
\hline \multirow[t]{2}{*}{34.} & DSb 31 & 4 & S & 10.5 & MR & 3.5 & LR & 5.3 & HS & 276 & 657 \\
\hline & & -2.11 & & -3.3 & & -2 & & -2.41 & & & \\
\hline \multirow[t]{2}{*}{35.} & JS 21-05 & 1.45 & $\mathrm{R}$ & 9.6 & $\mathrm{MR}$ & 3.05 & $M R$ & 3 & MR & 610 & 1452 \\
\hline & & -1.4 & & -3.17 & & -1.88 & & -1.87 & & & \\
\hline \multirow[t]{2}{*}{36.} & JS 7152 & 1.55 & $\mathrm{R}$ & 10.2 & $\mathrm{MR}$ & 3.05 & $\mathrm{MR}$ & 1.13 & $\mathrm{HR}$ & 830 & 1976 \\
\hline & & -1.43 & & -3.27 & & -1.88 & & -1.22 & & & \\
\hline \multirow[t]{2}{*}{37.} & RKS 18 & 0.43 & $\mathrm{R}$ & 8.85 & $\mathrm{R}$ & 3.15 & MR & 2.63 & MR & 492.5 & 1173 \\
\hline & & -0.96 & & -3.05 & & -1.91 & & -1.76 & & & \\
\hline \multirow[t]{4}{*}{38.} & JS 335 & 0.32 & $R$ & 12 & LR & 3.3 & LR & 2.8 & $\mathrm{MR}$ & 725 & 1726 \\
\hline & & -0.9 & & -3.52 & & -1.94 & & -1.82 & & & \\
\hline & SEm \pm & 0.17 & & 0.21 & & 0.1 & & 0.12 & & 7.08 & \\
\hline & $\mathrm{CD}(p=0.05)$ & 0.49 & & 0.61 & & 0.27 & & 0.34 & & 20.27 & \\
\hline
\end{tabular}


** Figures in the table are mean values and those in parenthesis are square root transformed values; HR: Highly Resistant; R: Resistant; MR: Moderately Resistant; LR: Low Resistant; S: Susceptible; HS: Highly susceptible

5-19, NRC 125, NRC 127, SL 113, DS 3106, AMS MB 5-18, MACS 1505, KDS 980, DSb 31, JS 2105, JS 7152) showed moderate resistance, whereas sixteen genotypes (PS 1589, SL 1104, KDS 1045, DSb 32, RVS 2009-9, PS 1587, NRC 126, KDS 921, MAUS 711, RSC 10-71, PS 1006, TS 70, VLS 93, RSC 10-52, NRC 124 and RKS 18) showed resistance and JS 21-08 was found to be susceptible (Table 1).

Similar research study has been done by researchers over the years like Arioglu (1987) who screened 109 soybean cultivars against whitefly between 1976 and 1986 and 42 cultivars were found to be highly resistant, 25 cultivars resistant, 16 cultivars moderately resistant, 14 cultivars susceptible and 12 cultivars highly susceptible.

3.3. Response of soybean genotypes against flea beetle (Systena sp.)

The adult flea beetle population ranged from 1.63 to 4.80 $\mathrm{mrl}^{-1}$ (Table 1) in different genotypes of soybean. Out of the thirty-eight genotypes screened, MAUS 711 and DS 3106 were found to be a highly susceptible genotype against flea beetle as it recorded 4.75 and 4.80 adult $\mathrm{mrl}^{-1}$, respectively. NSO 626 showed high resistance with a lowest mean insect count of 1.63adult $\mathrm{mrl}^{-1}$. Nine genotypes (RVS 2009-9, NRC 126, KDS 921, Himso 1687, TS 70, SL 113, RSC 10-52, DSb 31and JS 335) exhibited low resistance and thirteen genotypes (VLS 92, PS 1589, KDS 1045, DSb 32, MACS 1520, PS 1587, NRC 125, RSC 1071, NRC 124, MACS 1505, JS 21-05, JS 7152 and RKS 18) showed moderate resistance, whereas seven genotypes (TS 80, MACS 1543, AMS-MB 5-19, VLS 93, NRC 127, AMS-MB 5-18 and KDS 980) showed resistance and six genotypes (JS 21-08, DS 3105, SL 1104, RSC 10-70, PS 1086and BAU 100) were found to be susceptible.

Similar research study was conducted by Sharma et al. (1994), they screened 16 soybean genotypes against some coleopteran defoliators and other insects and found that cultivars JS 335, NRC 2, Punjab 1 and genotypes DS 396, L 129 and Soja Savana was tolerant to overall insect damage. Genotype TGX 814-54D was found to be less damaged by defoliators, and TGX 342-53D and TGX 814-54D were reported to be less damaged by stem fly and girdle beetle.

\subsection{Response of soybean genotypes against stink bug (Nezara} viridula, Linneaus)

The adult stink bug population ranged from 0.4 to $5.9 \mathrm{mrl}^{-1}$ in different genotypes of soybean (Table 1). Out of the thirtyeight genotypes screened, five genotypes (AMS-MB5-19, SL 1113, RSC 10-52, NRC 124 and DSb 31) were found to be highly susceptible. Six genotypes (TS 80, JS 21-08, PS 1589, MACS 1520, PS 1086 and JS 7152) showed high resistance. Nine genotypes (KDS 1048, RVS 2009-9, PS 1587, NRC 126, NRC 921, NRC 125, RSC 10-71, BAU 100 and KDS 980) exhibited low resistance and ten genotypes (VLS 92, SL 1104, DSb 32,
MAUS 711, TS 70, VLS 93, MACS 1505, JS 21-05, RKS 18 and JS 335) showed moderate resistance, whereas three genotypes (MACS 1543, DS 3105, NSO 626) showed resistance and five genotypes (RSC 10-70, Himso 1687, NRC 127, DS 3106, AMSMB 5-18) were found to be susceptible.

Similar study was conducted by Jackai et al. (1988) who screened a number of soybean breeding lines and other genotypes for resistance to stink bugs under field conditions. TGx 713-09D, TGx 307-048D, TGx 306-036C and TGx 814-036D were categorized as the genotypes manifesting the highest level of field resistance.

3.5 Grain yield ( $\left.\mathrm{kg} \mathrm{ha}^{-1}\right)$ of soybean genotypes under the influence of the major insect pests

The yield reported from each of the genotype was recorded and tabulated. The best performance was reported by VLS 92 with $2119 \mathrm{~kg} \mathrm{ha}^{-1}$ followed by NRC 127 and KDS 980 with 2040 and $2017 \mathrm{~kg} \mathrm{ha}^{-1}$ respectively. The lowest grain yield was recorded in KDS 921 with 553.5 $\mathrm{kg} \mathrm{ha}^{-1}$ (Table 1).

In a similar study conducted by Manu and Patil (2015) it was found that the varieties like JS 335, RKS 18, JS 93-05, MAUS 61, DSb 21, DSb 1 and Bragg did not differ significantly with each other in respect to loss in seed yield. In the present study, two varieties JS 335 and RKS 18 reported good yield falling under high yielding varieties among the several other varieties screened. In another study reported by Sinha and Netem (2015), the grain yield from different varieties ranged from 1720 to $2220 \mathrm{~kg} \mathrm{ha}^{-1}$. Highest yield was recorded in NRC77 which was almost similar to that obtained in Bragg and NRC-37 with 2210 and $2200 \mathrm{~kg} \mathrm{ha}^{-1}$, respectively. The yield was obtained under the influence of coleopteran pest infestation.

\section{Conclusion}

Selection of superior varieties suitable for the cultivation in the region is of outmost importance as soybean is grown by the marginal farmers who cannot afford the cost to mitigate the biotic stresses. Most of the genotypes performed well and the best suited genotypes for the region in terms of resistance and yield under the influence of the major insect pest are SL 1104, VLS 93, DSb 32, BAU 100, NRC 125 and JS 335.

\section{References}

Anonymous, 2015. Soybean Processors Association of India (SOPA) www.sopa.org.

Arioglu, H.H., 1987. Screening of some soybean varieties for resistance to whitefly (Bemisia tabaci Genn.). Soybean Genetics Newsletter 14, 125-131.

Awasthi, M., Sharma, A.N., Kapoor, K.N., Singh, R.N., 2005. Screening of soybean germplasm, breeding lines and released varieties for resistance against stem fly, girdle beetle and green semilooper. Journal of Entomological 
Science 53 (4), 399-401.

Chouhan, O.P., Chouhan, G.S., Singh, Gurumukh, Kumber, B.K., Mishra, D.P., 2002. Variability in the contents of nutrients and antinutrients in different parts of soybean seeds. The Journal of Rural and Agricultural Research 2(2), 42-50.

FAO., 2013. FAOSTAT. Agriculture Organization of the United Nations (Statistical database). http://www.fao.org/ faostat/en/

Jackai, L.E.N., Dashiell, K.E., Bello, L. L., 1988. Evaluation of soybean genotypes for field resistance to stink bugs in Nigeria. Crop protection 7, 49-54.

Kumawat, M.M., Kumar, A., Bunker, G.K., 2010. Screening of soybean cultivars against girdle beetle. : Annals of Plant Protection Sciences 18(1), 246-247.

Manu, N., Patil, R.H., 2015. Screening of Soybean Varieties against Leaf Eating Caterpillars and Classification into Resistance Groups Based on Yield Potential and Loss. Soybean Research 13(1), 40-47.

Massoni, F., Frana, J., 2005. Si no es en sojaclas chinches donde están? Información técnica de cultivos de verano, Campaña 2005. Journal of Insect Science 12(104), 1-16.

McPherson, J.E., McPherson, R.M., 2000. Stink bugs of economic importance in North America \& Mexico. CRC LLC, Boca Raton, FL.

Netam, H.K., Kanwar, S.S., 2013. Screening of soybean varieties against girdle beetle and other Pests. International Journal of Plant Protection 6, 73-76.

Oerke, E.C., Dehne, H.W., 2004. Safeguarding productionlosses in major crops and the role of crop protection. Crop Protection. 23, 275-285.

Oliveira, C.M., Auad, A.M., Mendes, S.M., Frizzas, M. R., 2014. Crop losses and the economic impact of insect pests on
Brazilian Agriculture. Crop Protection 56, 50-54.

Pal, S., Ghimiray, T.S., Sharma, B.R., 2013. Reaction of soybean cultivars to leaf folders, Nacoleia spp.(Lepidoptera: Pyralidae) under mid hill conditions of Darjeeling, India. Agricultural Science Digest 33(4), 327-328.

Pinheiro, J.B., Vello, N.A., Rossetto, C.J., Zucchi, M.I., 2005. Potential of soybean genotypes as insect resistance sources. Crop Breeding and applied Biotechnology 5, 293-300.

Sharma, A.N., 1996. Comparision of two screening procedures and classification of soybean genotypes into insectresistant groups. Internatinal Journal of Pest Management 42(4), 307-310.

Sharma, S.N., Karmakar, P.G., Bhatnagar, P.S., Shukla, R.K., Singh, R.N., 1994. Status of soybean varieties for tolerance to stem fly. Journal of Maharashtra Agricultural University 19(2), 319-320.

Singh, R., Sharma, A., 2013. Soybean production technology for better yield in Morung Express. 3 Sept, $2013 \mathrm{http}: / /$ morungexpress.com/soybean-production-technologyfor-better-yield/. Accessed on 09 May 2016.

Sinha, D., Netam, H.K., 2013. Screening of soybean varieties against Girdle beetle. Journal of Plant Development Sciences 5(1), 73-76.

Suharsono, Sulistyowati, L., 2012. Expression of resistance of soybean to the pod sucking bug Riptortus linearis $F$. (Hemiptera: Coreidae). Agrivita 34(1), 55-59.

Tamang, J.P., 2015. Naturally fermented ethnic soybean foods of India. Journal of Ethnic Foods. 2, 8-17.

USDA, 2016-17. https://www.statista.com. 